\title{
Influence of weather conditions during swath drying on the nutritive value of hay
}

\author{
MAIJA-LIISA SALO \\ Department of Animal Husbandry, University of Helsinki, 00710 Helsinki 71
}

\section{ERKKI VIRTANEN}

Agricultural Research Centre, North Savo Experimental Station, 71750 Maaninka

\footnotetext{
Abstract. The influence of weather conditions during swath drying on the composition and nutritive value of hay was investigated at seven plots of conditioned Gramineae hay. Hays were tedded 1-2 times a day except on rainy days. Five of the hays were sampled and analyzed daily, two at cutting and baling and on one other day only.

One hay was harvested in fine weather and dried in just over two days. The protein content decreased, but the sugar content remained unchanged. The f.u. value (fattening feed unit $=0.7 \times$ starch unit) fell 4 $\%$, the DCP value $12 \%$.

A second hay was exposed to eight days of rain. The main changes were a rise in lignin content and decrease in digestibility. The protein and sugar contents and the pepsin solubility of protein changed very little. The f.u. value fell $18 \%$, the DCP value $2 \%$.

Five other hays were 6-12 days as swath in variable rainy and dry weather conditions. The quality changed depending on the time, duration and amount of rain. The decreases of $f . u$. and DCP values were $10-30 \%$ and $8-28 \%$, respectively. The contents of sugar, ash and crude fat fell $31-64,3-51$ and $36-39 \%$, while the crude fibre content rose 6-23\%.

The reduction in the DCP value in bad weather depended more on the decrease of pepsin solubility of protein than on the decrease of protein content.

The potassium content of hay proved to be a good measure of the leaching due to rain. In the present hays the potassium content decreased $0-79 \%$.

The average total losses calculated on the basis of lignin content of hay were as follows (ranges in parenthesis): DM $22 \%$ (12-29), F. u. $35 \%$ (15-51), DCP $32 \%(22-49)$, sugars + fructosan $50 \%(12-74)$ and ash $33 \%(18-65)$.
}

\section{Introduction}

Haymaking in Finland is always at the risk of the unstable weather conditions. The quality of hay has recently become still more dependent on the weather, as the conventional drying on stakes has given way to swath drying and baling. 
The main causes of the reduction in the nutritive value of hay during swath drying are respiration, microbial degradation, leaching due to rain, and scattering of leaves in mechanical treatments.

Sugars and fructosan are consumed in respiration. At the same time photosynthesis continues until a DM content of 30-35\% is reached (BECKHOFF et al. 1979), and in favourable conditions generation of sugars may even exceed the loss due to respiration (VAN BOCKSTAELE et al. 1979). Respiration slows down as the drying advances, and terminates with the destruction of mitochondria at the DM level of 60-70 \% (DEVAD et al. 1974).

The microbial activity likewise causes decomposition of water soluble carbohydrates, and its effect is difficult to distinguish from the effect of respiration. Rain increases decomposition, though not very much in freshly cut grass since the waxy cuticula then forms a protective layer. Water penetrates easily into dried and especially into conditioned dried hay and stimulates microbial growth. High temperature increases its intensity. The rain also leaches nutrients from the dry hay and the separate losses derived from decomposition and leaching are difficult to distinguish (HONIG 1979).

Mechanical treatments of hay tend to scatter the leaves, the losses being linear with the DM content of hay and the frequency of tedding. The losses are highest during drying from 70 to $80 \%$ DM content, and tedding twice a day instead of once doubles them (JEPPSON 1981). Hay must, however, dry to about $80 \%$ DM level to prevent it from spoiling.

The purpose of this study was to investigate the changes that occur in the composition and nutritive value of conditioned hay during swath drying in the field and baling.

\section{Materials and methods}

The experiment was carried out in the years 1977-1979. The hays of seven plots were made at the Experimental Station, which is located in the central part of Finland $\left(63.2^{\circ} \mathrm{N}\right)$.

Haymaking followed usual farming practice: hay was cut with a flail mower conditioner and tedded 1-2 times a day with a rotary rake-tedder or side delivery rake-tedder. No tedding was done on rainy days. The samples were taken from an area $6 \mathrm{~m} \times 80 \mathrm{~m}, 2-3$ parallel samples each time. In the first year samples were taken 2-4 times a day, in the second year once a day, and in the third year only on cutting and baling days and once in between. Meteorological observations were made three times a day.

At the Experimental Station the dry matter content of the grass samples was determined at $103^{\circ} \mathrm{C}$, and samples for analyses were prepared by drying first at $100^{\circ} \mathrm{C}$ for $30-50 \mathrm{~min}$, depending on the moisture, and continuing the drying at $50^{\circ} \mathrm{C}$. This method preserves the sugar content unchanged (SALO and KOTILAINEN 1970).

The samples were analyzed for Weende methods, the sum of sugars and fructosan, crude lignin and pepsin soluble crude protein (SALO 1965), in vitro digestibility of organic matter (TILLEY and TERRY 1963), phosphorus 
(TAUSSKY and SHORR 1953), and cations (atomic absorption spectophotometry, Varian Techtron AA 1000). From the results were calculated the D value, the $\mathrm{f}$. $u$. value (fattening feed unit $=0.7 \times$ starch unit) (ANON 1969), and the DCP value (pepsin soluble crude protein $\times 0.85$ ) (ANON 1975). The losses of nutrients were calculated on the basis of lignin content of hay.

\section{Results and discussion}

The analytical results and the most important primary data are presented as averages of 1 or 2 days samples (Tables $1-3$ ). The percentage changes in the chemical components between the times of cutting and baling are given too. The moisture of hays is expressed as ranges for each 1- or 2-day period. The term "sugars" means the sum of sugars and fructosan. The hays are grouped into four groups according to the weather conditions during harvesting and drying: A: fair-weather, B: rain every day, C: rain commencing when hay dry, D: alternate rainy and dry weather.

It must be remembered that, hay being a heterogenous material, the composition varies even between parallel samples. In the present study the averages for factors determined in every sample (Weende analyses, sugars, in vitro digestibility) can be considered reliable because of the large number of samples. Minerals, lignin and pepsin soluble crude protein were usually analyzed only in samples taken on cutting and baling days.

\section{A. Fair-weather conditions}

One hay of the seven was harvested and dried in clear weather (Table 1, A). Conditions were ideal: temperature $16-27^{\circ} \mathrm{C}$, humidity $55-35 \%$, and wind speed $2-5 \mathrm{~m} / \mathrm{s}$. The conditioned timothy hay $(98 \%$ Phleum pratense, 2 $\%$ Festuca pratensis) dried fit for baling in just over two days. The sugar

Table 1. Changes in the composition and solubility of hay during swath drying: A) no rain, B) rain every day

\begin{tabular}{|c|c|c|c|c|c|c|c|c|c|c|c|c|c|c|c|c|c|c|}
\hline & \multirow{2}{*}{$\begin{array}{l}\text { Days } \\
\text { from } \\
\text { cutting }\end{array}$} & \multirow{2}{*}{$\begin{array}{c}\text { Number } \\
\text { of } \\
\text { samples }\end{array}$} & \multirow{2}{*}{$\begin{array}{l}\text { Rain } \\
\text { mm }\end{array}$} & \multirow{2}{*}{$\begin{array}{c}\text { Moisture } \\
\text { of hay } \\
\%\end{array}$} & \multicolumn{5}{|c|}{$\%$ of dry matter } & \multirow{2}{*}{$\begin{array}{c}\text { Digestib. } \\
\text { of } \mathrm{OM} \\
\text { in vitro } \\
\%\end{array}$} & \multirow{2}{*}{$\begin{array}{c}\text { Pepsin } \\
\text { solubility } \\
\text { of protein } \\
\%\end{array}$} & \multicolumn{3}{|c|}{$\mathrm{g} / \mathrm{kg}$ DM } & \multirow[b]{2}{*}{ P } & \multicolumn{3}{|c|}{$\mathrm{mg} / \mathrm{kg}$ DM } \\
\hline & & & & & $\begin{array}{l}\text { crudec } \\
\text { protein }\end{array}$ & $\begin{array}{l}\text { crude } \\
\text { fibre }\end{array}$ & ashs & rugars li & lignin & & & $\mathrm{Ca}_{\mathrm{a}}$ & $\mathrm{Mg}$ & $\mathrm{K}$ & & Mn & $\mathrm{Zn}$ & $\mathrm{Cu}$ \\
\hline & \multicolumn{18}{|c|}{ A. No rain } \\
\hline & 0 & 4 & 0,0 & $n-47$ & 12,9 & 32,5 & 7,8 & 10,8 & 6,3 & 67,9 & $n$ & 3,4 & 1,1 & 33,1 & 2,2 & 63 & 40 & 4,1 \\
\hline & 1 & 4 & 0,0 & $42-27$ & 12,5 & 34,9 & 7,6 & 10,5 & - & 67,1 & - & 3,2 & 1,1 & 32,3 & 2,1 & 50 & 28 & 4.6 \\
\hline & 2 & 2 & 0,0 & $26-21$ & 11,4 & 33,5 & 7,3 & 10,8 & 7,2 & 65,7 & 76 & 2,7 & 1.0 & 33,1 & 2,1 & 52 & 33 & 4,3 \\
\hline Total & 2 & 10 & 0,0 & & & & & & & & & & & & & & & \\
\hline \multirow[t]{8}{*}{ Changes, } & $\%$ & & & & -12 & +3 & -6 & 0 & +14 & -3 & -1 & -21 & -9 & 0 & -5 & -17 & -18 & +5 \\
\hline & \multicolumn{18}{|c|}{ B. Rain every day } \\
\hline & 0 & 3 & 5,6 & $80-80$ & 14,0 & 29,2 & 6,7 & 11,9 & 6,5 & 65,3 & 70 & 4,0 & 2,1 & 25,8 & 1,8 & 62 & 25 & 5,7 \\
\hline & 1 & 4 & 2,2 & $82-84$ & 14,2 & 29,8 & 6.2 & 12,1 & - & 64,6 & 70 & - & - & - & - & - & - & 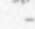 \\
\hline & 2 & 2 & 20,5 & $82-80$ & 14,6 & 30,1 & 6,6 & 11,1 & - & 63,1 & - & - & - & - & - & - & - & - \\
\hline & $3-4$ & 4 & 9,7 & $77-81$ & 14,1 & 30,1 & 6,1 & 12,1 & - & 60,7 & - & - & - & - & - & - & - & - \\
\hline & $5-6$ & 4 & 6,6 & $81-63$ & 14,6 & 29,8 & 6,3 & 11,7 & - & 60,4 & - & - & - - & - & - & - & - & - \\
\hline & $7-8$ & 4 & 21,1 & $75-37$ & 14,4 & 31,1 & 6,1 & 10,4 & 7,9 & 58,2 & 67 & 4,1 & 2,1 & 21,9 & 1,8 & 53 & 22 & 5,4 \\
\hline Total & 8 & 21 & 65,7 & & & & & & & & & & & & & & & \\
\hline Changes, & $\%$ & & & & +3 & +7 & -9 & -13 & +22 & -11 & $\rightarrow$ & +3 & 0 & -15 & 0 & -15 & -12 & -5 \\
\hline
\end{tabular}


content remained unchanged, indicating that photosynthesis compensated for losses due to respiration and microbial degradation. The same has been found earlier (NILSSON 1979). The mechanical treatments caused loss of leaves, which is seen as lowered crude protein and raised fibre contents. Under fair-weather conditions the cruching of hay has been found beneficial (BECKHOFF et al. 1979, DERNEDDE 1979).

\section{B. Rain every day}

The hay B (Table 1) was cut during a rainy period and was eight days wet in the field. The air temperature was $9-17^{\circ} \mathrm{C}$ and the relative humidity $65-100 \%$. On the eighth day the moist hay was baled and used for preservation studies. The hay was mixed in botanical composition (Dactylis glomerate $28 \%$, Poa pratensis $37 \%$, Phleum pratense $8 \%$, Triticum repens $7 \%$, Taraxacum officinale $20 \%$ ).

This hay was not tedded until the last two days when it still was moist, so no scattering occurred. The sugar content decreased only slightly indicating that respiration and microbial decomposition were very moderate. In the continuous daylight of midsummer (the sun over the horizon about $20 \mathrm{~h} / \mathrm{d}$ ), however, the living cut grass possibly replaces by photosynthesis a good part of the sugar that the respiration at low temperature decomposes. The decrease of digestibility and increase of lignin content hardly depended exclusively on the decomposition and leaching, but a good part of these changes might arise from the normal tendency of grass to become more fibrous with age. In the cut grass, however, this process presumably proceeds more slowly than in the standing crop.

The conclusion is that the cut grass can lie in daily rain for a week with only moderate decrease in the nutritive value. The protein value in particular seems to decrease much more slowly than in the standing crop during the same time.

\section{Rain commencing when hay dry}

The damage is heaviest when rain falls on the dry or nearly dry hay (Table 2). Hay C 1 (Festuca pratensis $68 \%$, Phleum pratense $32 \%$ ) dried during three initial days, but was not baled. Changes in composition were then the same as in hay A (Table 1). Thereafter followed a week of rainy weather with temperatures of $10-16^{\circ} \mathrm{C}$ and relative humidity of $60-100 \%$. In the beginning the rain was light and did not cause substantial leaching, but it did create a suitable environment for microbial growth. On the eighth day a hard rain fell $(20.5 \mathrm{~mm})$ and leaching completed the damage.

The high increase of fibre content and decrease of protein value indicate that many damaging factors were involved. Potassium content seems to be a good measure of the leaching - in this hay it fell $79 \%$. Leaching also decreases drastically the ash content as a whole. 
Table 2. Changes in the composition and solubility of hay during swath drying: C) rain commencing when hay dry

\begin{tabular}{|c|c|c|c|c|c|c|c|c|c|c|c|c|c|c|c|c|c|c|}
\hline & \multirow{2}{*}{$\begin{array}{l}\text { Days } \\
\text { from } \\
\text { cutting }\end{array}$} & \multirow{2}{*}{$\begin{array}{c}\text { Number } \\
\text { of } \\
\text { samples }\end{array}$} & \multirow{2}{*}{$\begin{array}{l}\text { Rain } \\
\text { mm }\end{array}$} & \multirow{2}{*}{$\begin{array}{c}\text { Moisture } \\
\text { of hay } \\
\%\end{array}$} & \multicolumn{5}{|c|}{$\%$ of dry matter } & \multirow{2}{*}{$\begin{array}{c}\text { Digestib. } \\
\text { of OM } \\
\text { in vitro } \\
\%\end{array}$} & \multirow{2}{*}{$\begin{array}{l}\text { Pepsin } \\
\text { solubility } \\
\text { of protein } \\
\%\end{array}$} & \multicolumn{3}{|c|}{$\mathrm{g} / \mathrm{kg}$ DM } & \multirow[b]{2}{*}{$\mathrm{P}$} & \multicolumn{3}{|c|}{$\mathrm{mg} / \mathrm{kg}$ DM } \\
\hline & & & & & $\begin{array}{l}\text { crudect } \\
\text { protein }\end{array}$ & $\begin{array}{l}\text { crude } \\
\text { fibre }\end{array}$ & ashs & sugar li & lignin & & & Ca & $\mathrm{Mg}$ & $\mathrm{K}$ & & Mn & $\mathrm{Zn}$ & $\mathrm{Cu}$ \\
\hline & \multicolumn{4}{|c|}{ C 1. Six days in rain after drying } & & & & & & & & & & & & & & \\
\hline & 0 & 4 & 0,0 & $73-41$ & 10,7 & 34,1 & 8,3 & 11,0 & 6,7 & 66,8 & 73 & 4,1 & 1,4 & 36,3 & 2,6 & 69 & 41 & 4,6 \\
\hline & 1 & 4 & 0,0 & $46-22$ & 10,3 & 35,2 & 8,2 & 10,6 & - & 65,2 & - & - & - & - & - & - & - & - \\
\hline & $4-5$ & 4 & 6,9 & $53-78$ & 9,8 & 36,8 & 7,2 & 9,5 & 7,6 & 61,2 & 66 & - & - & - & - & - & - & - \\
\hline & $6-7$ & 4 & 7,8 & $67-80$ & 10,0 & 39,1 & 5,8 & 6,0 & - & 58,2 & - & - & - & - & - & - & - & - \\
\hline & $8-9$ & 2 & 23,9 & $72-44$ & 9,6 & 41,9 & 4,1 & 4,0 & 9,4 & 56,0 & 59 & 3,2 & 1,0 & 7,6 & 1,6 & 58 & 29 & 2,9 \\
\hline Total & 9 & 18 & 38,6 & & & & & & & & & & & & & & & \\
\hline \multirow[t]{5}{*}{ Changes, } & $\%$ & & & & -10 & +23 & -51 & -64 & +40 & -16 & -19 & -22 & -29 & -79 & -38 & -16 & -29 & -37 \\
\hline & \multicolumn{4}{|c|}{ C. 2. Four days in rain after drying } & & & & & & & & & & & & & & \\
\hline & 0 & 2 & $\begin{array}{l}0,0 \\
0.2\end{array}$ & 73 & 12,0 & 31,9 & 5,3 & 15,0 & 7,3 & 66,2 & 78 & 2,6 & 1,0 & 24,5 & 2,1 & 59 & 30 & 3,3 \\
\hline & 3 & 2 & $\begin{array}{r}0,0 \\
14,7\end{array}$ & 28 & 12,4 & 32,2 & 5,7 & 13,7 & - & 64,1 & - & 2,5 & 0,9 & 25,2 & 2,0 & 63 & 27 & 3,0 \\
\hline & 7 & 2 & 0,0 & 23 & 12,3 & 36,1 & 4,2 & 7,3 & 10,0 & 58,0 & 67 & 2,2 & 0,8 & 15,2 & 1,8 & 58 & 27 & 3,0 \\
\hline Total & 7 & 6 & 16,7 & & & & & & & & & & & & & & & \\
\hline Changes, & $\%$ & & & & +3 & +13 & -21 & -51 & +37 & -12 & -14 & -15 & -20 & -38 & -14 & -2 & -10 & -9 \\
\hline
\end{tabular}

The hay C 2, after drying a shorter period was also exposed to rain but leaching was not so extensive as for hay $\mathrm{C} 1$. As a consequence the DCP value and the sugar content, however, decreased by half.

Earlier studies have shown that the losses due to rain depend essentially on the DM content of hay and the amount of rain (BECKHOFF 1981). MØLLER and SKOVBORG (1971) indicated, that $20 \mathrm{~mm}$ atrificial rain caused $8-10 \%$ dry matter loss in hay with $74 \%$ DM content, but only $1-2 \%$ loss in hay with $20 \% \mathrm{DM}$. The losses have always been higher in conditioned than in unconditioned hay.

\section{Alternate rainy and dry weather}

The most ill-fortuned hay in this group was D 1 (Table 3). It was twelve days as swath and twice became partially dry at the end of this period. The rainfalls were generally rather light, but one heavy rain $(26.6 \mathrm{~mm})$ fell. The relative humidity was $55-95 \%$, and the temperature first high $\left(15-22^{\circ} \mathrm{C}\right)$, then low $\left(9-16^{\circ} \mathrm{C}\right)$. The $28 \%$ decrease of potassium content of this turf field hay indicates that leaching occurred in addition to decomposition. The high protein content reflects the high proportion of couch-grass, which develops to ear emergence a good week later than the cultivated Gramineae grasses (botanical composition: Triticum repens $51 \%$, Phleum pratense $23 \%$, Poa pratensis $15 \%$, Festuca pratensis $5 \%$, Taraxacum officinale $6 \%$ ).

D 2 was a pure Gramineae hay (Phleum pratense $50 \%$, Festuca pratensis $50 \%$ ). The daily although light rains maintained high relative humidity $(60-90)$, but the temperature was low $\left(10-16^{\circ} \mathrm{C}\right)$ and losses were relatively small. The mere $8 \%$ decrease of potassium content indicates that the leaching was slight.

In the case of hay D 3 the heaviest rains fell onto the freshly cut grass and leaching remained slight (decrease of potassium $5 \%$ ). The warm $\left(15-22^{\circ} \mathrm{C}\right)$ and moist (50-90\%) weather favoured microbial growth, and the loss of sugars was high. 
Table 3. Changes in the composition and solubility of hay during swath drying: D) alternate rain and dry weather

\begin{tabular}{|c|c|c|c|c|c|c|c|c|c|c|c|c|c|c|c|c|c|c|}
\hline & \multirow{2}{*}{$\begin{array}{l}\text { Days } \\
\text { from } \\
\text { cutting }\end{array}$} & \multirow{2}{*}{$\begin{array}{c}\text { Number } \\
\text { of } \\
\text { samples }\end{array}$} & \multirow{2}{*}{$\begin{array}{l}\text { Rain } \\
\mathrm{mm}\end{array}$} & \multirow{2}{*}{$\begin{array}{c}\text { Moisture } \\
\text { of hay } \\
\%\end{array}$} & \multicolumn{5}{|c|}{$\%$ of dry matter } & \multirow{2}{*}{$\begin{array}{c}\text { Digestib. } \\
\text { of } \mathrm{OM} \\
\text { in vitro } \\
\%\end{array}$} & \multirow{2}{*}{$\begin{array}{c}\text { Pepsin } \\
\text { solubility } \\
\text { of protein } \\
\%\end{array}$} & \multicolumn{3}{|c|}{$\mathrm{g} / \mathrm{kg}$ DM } & \multirow[b]{2}{*}{$\mathrm{P}$} & \multicolumn{3}{|c|}{$\mathrm{mg} / \mathrm{kg}$ DM } \\
\hline & & & & & $\begin{array}{l}\text { crude } \\
\text { protein }\end{array}$ & $\begin{array}{l}\text { crude } \\
\text { fibre }\end{array}$ & ashs & sugars li & lignin & & & $\mathrm{Ca}$ & $\mathrm{Mg}$ & K & & Mn & $\mathrm{Zn}$ & $\mathrm{Cu}$ \\
\hline & \multicolumn{4}{|c|}{ B 1. Twelve days drying period } & & & & & & & & & & & & & & \\
\hline & 0 & 3 & 0,1 & 74 & 15,5 & 30,4 & 4,7 & 11,5 & 7,1 & 66,1 & 76 & 3,8 & 2,1 & $11,1$. & 2,0 & 92 & 25 & 5,7 \\
\hline & $1-3$ & 6 & 27,6 & $48-70$ & 15,9 & 30,4 & 4,2 & 10,4 & - & 64,1 & - & - & - & - & - & - & - & - \\
\hline & $4-5$ & 4 & 5,0 & $79-50$ & 15,7 & 32,0 & 4,1 & 7,9 & - & 62,0 & - & - & - & - & - & - & - & - \\
\hline & $6-8$ & 6 & 5,7 & $57-27$ & 15,9 & 32,8 & 4,2 & 6,7 & - & 60,8 & - & - & - & - & - & - & - & - \\
\hline & $9-10$ & 4 & 1,0 & $41-27$ & 15,7 & 33,5 & 3,9 & 5,9 & - & 59,8 & - & - & - & - & - & - & - & - \\
\hline & 11 & 2 & 5,2 & 53 & 15,4 & 33,8 & 4,0 & 4,9 & - & 58,5 & - & - & - & - & - & - & - & - \\
\hline & 12 & 2 & 1,5 & 25 & 15,3 & 34,6 & 3,9 & 4,8 & 9,8 & 58,7 & 66 & 3,6 & 2,0 & 8,0 & 1,9 & 91 & 24 & 7,3 \\
\hline Total & 12 & 27 & 46,1 & & & & & & & & & & & & & & & \\
\hline \multirow{7}{*}{ Changes, } & $\%$ & & & & -1 & +14 & -17 & -58 & +38 & -11 & -13 & -5 & -5 & -28 & -5 & -1 & -4 & +28 \\
\hline & \multicolumn{4}{|c|}{ D. 2. Seven days drying period } & & & & & & & & & & & & & & \\
\hline & 0 & 3 & 2,6 & 78 & 12,3 & 31,4 & 6,7 & 13,0 & 7,6 & 64,0 & 74 & 3,4 & 1,4 & 27,4 & 2,3 & 63 & 40 & 5,4 \\
\hline & $1-3$ & 6 & 2,0 & $61-48$ & 12,0 & 32,3 & 7,1 & 12,0 & - & 63,1 & - & - & - & - & - & - & - & - \\
\hline & 4 & 2 & 5,2 & 64 & 12,8 & 33,4 & 6,5 & 9,1 & - & 60,1 & - & - & - & - & - & - & - & - \\
\hline & $5-6$ & 4 & 1,5 & $38-31$ & 11,9 & 33,6 & 6,4 & 9,0 & 9,1 & 59,2 & - & - & - & - & - & - & - & - \\
\hline & 7 & 2 & 0,0 & 25 & 11,4 & 34,0 & 6,4 & 9,0 & 9,1 & 58.7 & 65 & 3,5 & 1,3 & 25,1 & 2,3 & 59 & 33 & 5,0 \\
\hline Total & 7 & 17 & 11,3 & & & & & & & & & & & & & & & \\
\hline \multirow[t]{4}{*}{ Changes, } & $\%$ & & & & -7 & +8 & -5 & -31 & +20 & -8 & -12 & +3 & -7 & -8 & 0 & -6 & -18 & -7 \\
\hline & \multicolumn{4}{|c|}{ D 3, Six days drying period } & & & & & & & & & & & & & & \\
\hline & 0 & 2 & $\begin{array}{r}8,1 \\
10,1\end{array}$ & 82 & 13,2 & 33,5 & 6,9 & 12,2 & 7,7 & 63,0 & 78 & 3,2 & 1,3 & 27,6 & 1,8 & 73 & 29 & 6,0 \\
\hline & 6 & 2 & 0,0 & 21 & 13,4 & 35,6 & 6,7 & 6,4 & 9,6 & 59,7 & 71 & 3,1 & 1,2 & 26,3 & 1,7 & 72 & 29 & 5,7 \\
\hline $\begin{array}{l}\text { Total } \\
\text { Changes, }\end{array}$ & $\frac{6}{8}$ & 4 & 18.2 & & +2 & +6 & -3 & -46 & +25 & -5 & -9 & -3 & -8 & -5 & -6 & -1 & 0 & -5 \\
\hline
\end{tabular}

The conditioning was bad for hays of groups B, C and D (BECKHOFF et al. 1979, DERNEDDE 1979).

The hays C 2, D 1, D 2 and D 3 were also analyzed for ether extract. The contents at cutting were $2.3-2.8 \%$ of DM, and at baling $1.4-1.8 \%$ of DM. The decrease was uniformly $36-39 \%$. Besides lipids, ether dissolves malic and citric acids, which like sugars decompose and leach easily. The decrease might therefore reflect loss mainly of this part of the crude fat.

\section{Changes in the nutritive value}

The net energy value was calculated as fattening feed unit (f. u. $=0.7 \times$ starch unit), which takes account of the digestibility and the crude fibre content. The basis for the calculation of the digestibility coefficients was the in vitro digestibility of organic matter, and the pepsin-soluble crude protein content multiplied by 0.85 .

The changes in the nutritive value depended essentially on the point of time and the duration and amount of rain (Table 4). When the hay was harvested in fine weather (A), its energy value fell very little, and the protein value more, because the tedding scattered leaves rich in protein.

When the newly cut hay was exposed to continuous rain for eight days, its sugar and protein contents remained nearly unchanged, but the digestibility diminished. The hays that suffered most were those that first dried and then were exposed to long periods of rain (C 1 and C 2). Ill-fated, too, was the hay that during twelve-days drying period was exposed to rain and dry weather alternately (D 1). Taking all hays together, the D value decreased 
Table 4. Changes in the nutritive value of hay during swath drying under different weather conditions. Hays from Tables 1-3.

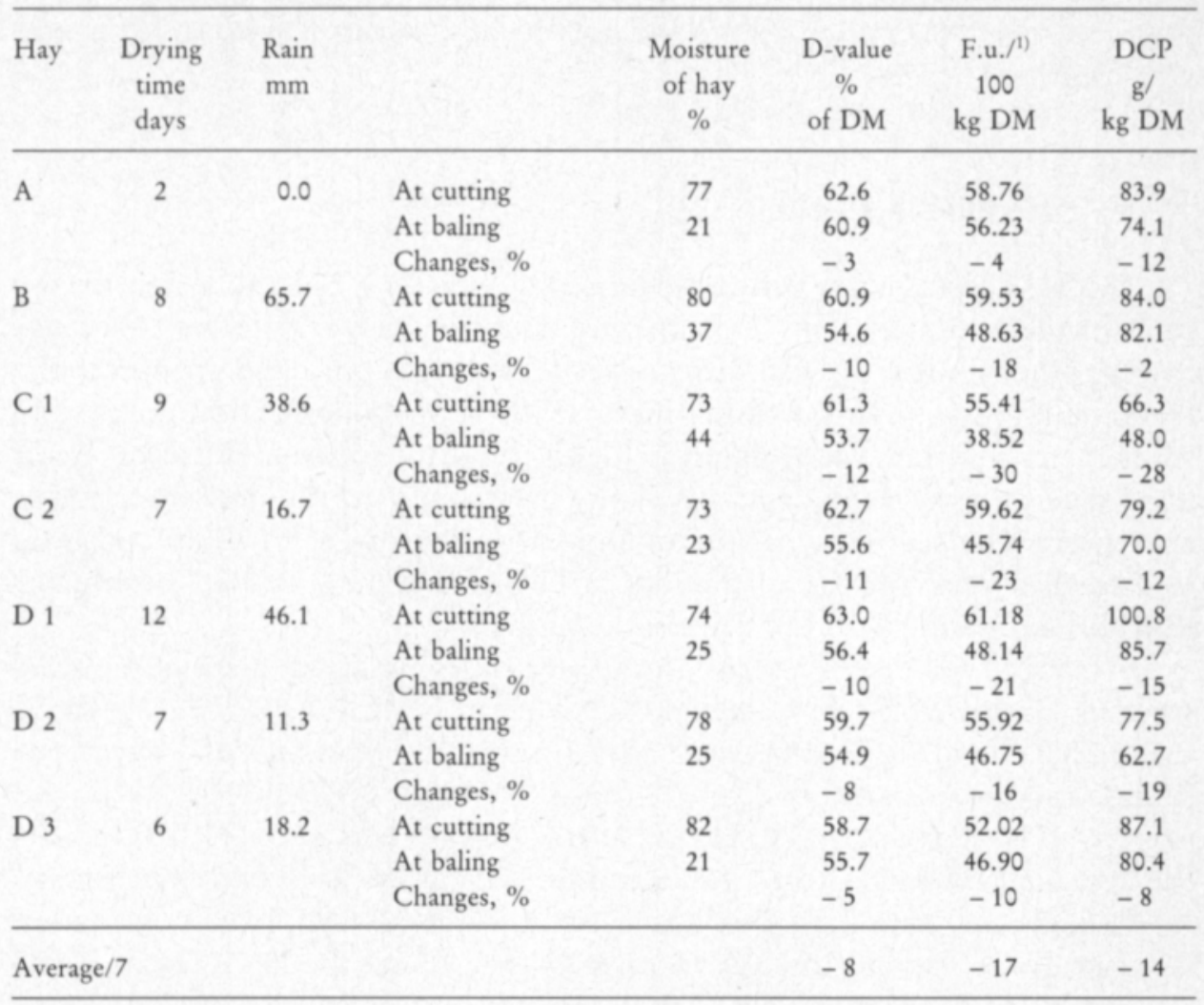

${ }^{1)}$ F. u. $=$ fattening feed unit $=0.7 \times$ starch unit

Table 5. Total losses (\%) during drying calculated on the basis of lignin content.

\begin{tabular}{lccccc}
\hline Hay & DM & F.u. & DCP & Sugars & Ash \\
\hline A & 12 & 15 & 22 & 12 & 18 \\
B & 18 & 33 & 20 & 28 & 25 \\
C 1 & 29 & 51 & 49 & 74 & 65 \\
C 2 & 27 & 44 & 35 & 64 & 42 \\
D 1 & 28 & 43 & 39 & 70 & 40 \\
D 2 & 17 & 31 & 33 & 43 & 21 \\
D 3 & 20 & 28 & 26 & 58 & 22 \\
\hline Average/7 & 22 & 35 & 32 & 50 & 33 \\
\hline
\end{tabular}

between 3 and $12 \%$, the f. u. value between 4 and $30 \%$, and the DCP value between 2 and $28 \%$.

There are few published investigations to be used for comparison. LINGVALL and NILSSON (1979) found in metabolic studies on sheep - and very similarily in in vitro digestibility studies - that the ME value or swath 
dried hay decreased in the absence of rain about $7 \%$ and with rain $25 \%$. The DCP values diminished 20 and $37 \%$, respectively. Judging by the composition, their hay was younger than the present hays and consisted of legume as well as grass.

\section{Total losses during swath drying}

The DM losses were not determined by weighing but calculated on the basis of the lignin content. This method is not entirely satisfactory, because among other things, the scattering of leaves and the continued growth of the freshly cut grass in rainy weather increase the lignin content from the cutting value. On the other hand, lignin is highly resistant to decomposition by at least anaerobic microbial activity. The repeatability of the determination is also good. The scattering of leaves and the growth of the freshly cut grass lead to an overestimation of the loss of DM, while the possible decomposition of lignin weighs in the reverse direction.

Investigations of DM losses during swath drying are numerous. In good weather, losses of 5-15\% (ref. LINGVALL and NILSSON 1979), 12-15\% (BECKHOFF et al. 1979, 1981) and 15-20\% (BREIREM et al. 1967) have been found, and in bad weather 25-30\% (BREIREM et al. 1967, HONIG 1979) and even over $40 \%$ (ref. LINGVALL and NILSSON 1979). CLASON (1979) reports the average DM losses to be $16 \%$ in normal and $24 \%$ in bad weather.

F. u. losses found in Norway (BREIREM et al. 1967) were for good weather 27-36 \%, and for bad weather 45-54 \%, and the DCP losses 30-35 $\%$, and $50-55 \%$, respectively. The figures are high as are also the DM losses reported above by the same investigators. Somewhat lower f. u. and DCP losses have been reported from central Europe and from Sweden in the 1930's (WATSON and NASH 1960).

The nutrient losses found in the present study are within these wide ranges. Hays C 1, C 2 and D 1 fall in the "bad weather" group, hay A is very good, and the others can be classed as "normal". The low DCP losses of the present hays are explained by the low protein content of the Gramineae species. Elsewhere in the world hay generally consists of grass and legume.

\section{References}

ANON. 1969. NJF Fodermiddeltabel. 40 p. Gjøvik.

ANON. 1975. Att välja proteinkälla. Husdjur 1975/8: 6-7.

BECKHOFF, J. 1981. Feldverluste beim Anwelken und Trocknen bei unterschiedlichen Grünlanderträgen. Wirtschaftseigene Futter 27: 121-130.

BECKHOFF, J., DERNEDDE, W., HONIG, H. \& SCHURIG, M. 1979. Einfluss neuer Mähaufbereiter auf Trocknung und Feldluste bei der Gewinnung von Anwelksilage und Heu. Wirtschaftseigene Futter 25: 5-19.

BREIREM, K., SAUE, O. \& EKERN, A. 1967. Generelle probleme; forbindelse med bruk av høy, silage og kunsttørket gras til melkekyr. NJF kongress 27.-30. 7. 1967. 
CLASON, Å. 1979. Höproduktion - från fält till mule. NJF seminar, seksjon VII. 13.-16. 2. 1979.

DERNEDDE, W. 1979. Treatments to increase the drying rate of cut forage. Proc. Conf. Forage conservation in the 80's: 61-66.

DEVAD, C., NILSSON, B. \& MAGNUSSON, E. 1974. Höberedning. Lantbr.högsk. Konsulentavd. Stencilserie Teknik $55.57 \mathrm{p}$.

HONIG, H. 1979. Mechanical and respiration losses during pre-wilting of grass. Proc. Conf. Forage conservation in the 80' s : 201-204.

JEPPSON, R. 1981. Förtorkning vid höberedning. Jordbr.tekn. Inst. Medd. 389. 51 p.

LINGVALL, P. \& NILSSON, E. 1979. Efficient hay systems. Proc. Conf. Forage conservation in the 80's: $175-185$.

MØLLER, E. \& SKOVBORG, E. B. 1971. Skårlagring og skårbehandling av graesmarksafgrøder til fortørring. Tidskr. Planteavl. 75: 483-501.

NILSSON, E. 1979. Hö - kvalitet och skördeutbyte - teknik. NJF seminar, seksjon VII. 13.-16. 2. 1979.

SALO, M.-L. 1965. Determination of carbohydrate fractions in animal foods and faeces. Acta Agr. Fenn. 105: 1-102.

SALO, M.-L. \& KOTILAINEN, K. 1970. Drying of herbage samples for analyses. J. Scient. Agric. Soc. Finl. 42: 173-179.

TAUSSKY, H. H. \& SHORR, E. 1953. A microcolorimetric method for the determination of inorganic phosphorus. J. Biol. Chem. 202: 675-685.

TILLEY, J. M. A. \& TERRY, R. A. 1963. A two-stage technique for the in vitro digestion of forage crops. J. Br. Grassl. Soc. 18: 104-111.

VAN BOCKSTAELE, E. J., BEHAEGHE, T. J. \& BAETS; A. E. de 1979. Studies on the field losses of wilting grass. Proc. Conf. Forage conservation in the 80's: 205-209.

WATSON, S. J. \& NASH, M. J. 1960. The conservation of grass and forage crops. 758 p. Edinburgh.

Ms. received February 10, 1983.

\section{Säätilan vaikutus luokona kuivattavan heinän koostumukseen ja rehuarvoon.}

Maija-Liisa Salo,

Helsingin yliopisto, kotieläintieteen laitos, 00710 Helsinki 71

\section{Erkki Virtanen}

Maatalouden tutkimuskeskus, Pohjois-Savon koeasema, 71750 Maaninka

Luokona kuivattavan heinän rehuarvoa heikentävät kasvin hengitys, mikrobien hajoitustoiminta, sateiden aiheuttama ravintoaineiden huuhtoutuminen ja mekaanisten käsittelyjen aiheuttama kariseminen. Sateisena kautena pahin on mikrobitoiminta, poudalla kariseminen.

Murskatun Gramineae -heinän koostumuksen ja rehuarvon muutoksia luokokuivatusaikana tutkittiin Helsingin yliopiston kotieläintieteen laitoksen ja Pohjois-Savon koeaseman yhteistyönä seitsemästä heinäerästä vuosina 1977-1979. Heinä kaadettiin niittokelamurskaimella ja sitä pöyhittiin kelapöyhimellä tai ketjuharavalla 1-2 kertaa päivässä, jos sää edellytti pöyhimistä. Pääosa analyyseistä tehtiin päivittäin, pieni osa vain niitto- ja paalauspäivien näytteistä. Orgaanisen aineen sulavuus määritettiin in vitro -menetelmällä ja raakavalkuaisen sulavuus pepsiini- $\mathrm{HCl}$-liukoisuutena. Näiden tietojen ja koostumuksen perusteella laskettiin heinien ry- ja srv-arvot. 
Yksi seitsemästä heinäerästä korjattiin täyspoudalla ja päästiin paalaamaan jo $2 \frac{1}{2}$ päivän kuluttua. Heinän sokeripitoisuus pysyi muuttumattomana ja ry-arvo laski vain $4 \%$. Lehtien kariseminen aiheutti valkuaishävikkiä ja srv-arvo aleni $12 \%$.

Toinen heinäerä oli luokona jatkuvissa sateissa kahdeksan päivää, minkä jälkeen se paalattiin märkänä. Valkuaispitoisuus ja valkuaisen sulavuus pysyi lähes muuttumattomana ja sokeripitoisuuskin laski vain vähän. Ligniinipitoisuus nousi ja sen mukana sulavuus laski. Rehuyksikköarvo aleni $18 \%$, mutta srv-arvo vain $2 \%$.

Muut viisi heinäerää olivat luokona 6-12 pv. Niiden rehuarvoa alensivat kaikki tappiotekijät, sateiden ajoittumisesta, kestosta ja määrästä riippuen eri asteisina. Suurinta tuhoa teki kuivaan heinään tullut pitkään jatkunut sade. Tässä ryhmässä heinän ry-arvo aleni 10-30 \%, srv-arvo $8-28 \%$, sokeripitoisuus $31-64 \%$, tuhkapitoisuus 3-51\% ja raakarasvapitoisuus $35-39 \%$. Raakakuitupitoisuus nousi 6-23\%.

Vuoroin kuivahtavan ja kastuvan heinän valkuaisarvoa huononsi enemmän valkuaisen sulavuuden lasku kuin sen pitoisuuden aleneminen.

Heinän kalium-pitoisuus todettiin hyväksi huuhtoutumisen parametriksi. Tutkituissa heinissä K-pitoisuus aleni 0-79\%. $20 \mathrm{~mm} / \mathrm{pv}$ sademäärä kuivaan heinään sai aikaan suurta kaliumin hävikkiä, $5 \mathrm{~mm} / \mathrm{pv}$ ei vielä sanottavasti.

Heinän ligniinipitoisuutta indikaattorina käyttäen lasketut keskimääräiset kokonaistappiot (suluissa raja-arvot) olivat: kuiva-aine $22 \%$ (12-29), ry $35 \%$ (15-51), srv $32 \%(22-49)$, sokerit $50 \%(12-74)$ ja tuhka $33 \%(18-65)$.

Tutkimuskauteen osui keskitasoa sateisempia korjuukausia, minkä vuoksi keskiarvotappiot lienee katsottava Suomen normaaleja keskiarvoja suuremmiksi. 